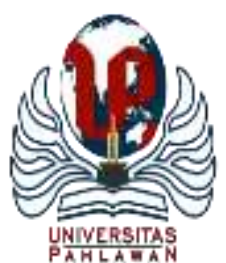

\title{
JURNALBASICEDU
}

Volume 6 Nomor 1 Tahun 2022 Halaman 372 - 385

Research \& Learningin Elementary Education https://jbasic.org/index.php/basicedu

\section{Pengaruh Literasi Membaca terhadap Pemahaman Moderasi Beragama Mahasiswa PGSD}

\author{
Neneng Sri Wulan ${ }^{1 凶}$, Hisny Fajrussalam² \\ Kampus UPI di Purwakarta, Indonesia ${ }^{1,2}$ \\ E-mail: neneng_sri wulan@upi.edu ${ }^{1}, \underline{\text { hfajrussalam@ @i.edu }}^{2}$
}

\begin{abstract}
Abstrak
Penelitian ini dilatarbelakangi oleh pentingnya kemampuan literasi membaca untuk memasuki dan memahami wahana keilmuan lainnya, termasuk pemahaman terhadap moderasi beragama. Pemahaman moderasi beragama diperlukan dalam kehidupan sosial masyarakat Indonesia yang hidup di tengah keberagaman agama dan keyakinan. Peneliti tertarik untuk mengkaji pengaruh literasi membaca terhadap pemahaman moderasi beragama mahasiswa. Sampel pada penelitian ini adalah 198 mahasiswa tingkat I Kampus UPI di Purwakarta. Metode yang digunakan dalam penelitian ini adalah survei eksplanatori. Teknik pengumpulan data yang dilakukan adalah tes dan kuesioner. Data dianalisis dengan teknik kuantitatif dan kualitatif. Hasil penelitian menunjukkan bahwa kemampuan literasi membaca mahasiswa masih tergolong cukup baik dengan rata-rata nilai tes 66,2. Nilai tertinggi adalah 100 dan nilai terendah adalah 15. Pemahaman moderasi bergama secara keseluruhan memiliki nilai persentase kumulatif sebesar 85,28\% dengan kategori baik. Berdasarkan hasil penelitian, kemampuan literasi membaca berpengaruh signifikan terhadap moderasi beragama, dengan total persentase pengaruh sebesar $17,39 \%$, sedangkan sisanya yaitu $82,61 \%$ dipengaruhi oleh faktor lain yang tidak diteliti.
\end{abstract}

Kata Kunci: Literasi Membaca, Pemahaman Moderasi Beragama, Mahasiswa PGSD.

\begin{abstract}
This research is motivated by the importance of reading literacy skills to enter and understand other scientific vehicles, including understanding religious moderation. We need an understanding of religious moderation in the social life of the Indonesian people who live amidst the diversity of religions and beliefs. Researchers are interested in studying the effect of reading literacy on students' understanding of religious moderation. The sample in this study was 198 level I students at UPI Campus in Purwakarta. The method used in this research is an explanatory survey with data collection techniques used are tests and questionnaires. Quantitative and qualitative techniques analyzed data. The results showed that students' reading literacy skills were still quite good, with an average test score of 66.2. The highest score is 100, and the lowest score is 15. The overall understanding of religious moderation has a cumulative percentage value of $85.28 \%$, with a good category. Based on the study results, reading literacy skills affect religious moderation, with a total percentage of influence of $17.39 \%$. In comparison, the remaining $82.61 \%$ is influenced by other factors not examined.
\end{abstract}

Keywords: Reading Literacy, the understanding of religious moderation, Primary Teacher Education Student

Copyright (c) 2022 Neneng Sri Wulan, Hisny Fajrussalam

$\triangle$ Corresponding author :

Email : neneng_sri_wulan@upi.edu

DOI : https://doi.org/10.31004/basicedu.v6i1.1927

ISSN 2580-3735 (Media Cetak)

ISSN 2580-1147 (Media Online)

Jurnal Basicedu Vol 6 No 1 Tahun 2022

p-ISSN 2580-3735 e-ISSN 2580-1147 


\section{PENDAHULUAN}

Literasi membaca merupakan salah satu kemampuan berbahasa yang perlu untuk dikuasai. Literasi membaca merupakan fondasi bagi seseorang untuk dapat memasuki dan memahami berbagai wahana keilmuan, begitu pula untuk memahami moderasi beragama.

Pemahaman mengenai moderasi beragama merupakan salah satu kemampuan yang diperlukan dalam kehidupan sosial masyarakat yang multikultural dan multidimensi. Dalam bahasa Arab, moderasi dikenal dengan kata wasath atau wasathiyah, yang memiliki padanan makna dengan kata tawassuth (tengah-tengah), i'tidal (adil), dan tawazun (berimbang). Orang yang menerapkan prinsip wasathiyah bisa disebut wasith. Dalam bahasa Arab pula, kata wasathiyah diartikan sebagai "pilihan terbaik". Apa pun kata yang dipakai, semuanya menyiratkan satu makna yang sama, yakni adil, yang dalam konteks ini berarti memilih posisi jalan tengah di antara berbagai pilihan ekstrem. Kata wasith bahkan sudah diserap ke dalam bahasa Indonesia menjadi kata 'wasit' yang memiliki tiga pengertian, yaitu: 1) penengah, perantara (misalnya dalam perdagangan, bisnis); 2) pelerai (pemisah, pendamai) antara yang berselisih; dan 3) pemimpin di pertandingan (Tim Penyusun Kemenag Republik Indonesia, 2019)

Pada di era 4.0 dan society 5.0 ini, pemahaman mengenai moderasi beragama perlu dihadirkan dalam berbagai sudut pandang. Perkembangan teknologi informasi yang pesat membuat informasi mengenai apapun, termasuk berita, opini, penelitian, dan hal lainnya mengenai kehidupan beragama, dapat diakses pada beragam media, seperti media massa, media sosial, dan lainnya. Berita atau opini yang dihadirkan tersebut terkadang dapat dipertanggung jawabkan kesahihannya, namun sebagian lagi terkadang tidak dapat dipertanggung jawabkan atau tidak jelas sumbernya / hoax. Untuk menyaring berita atau opini tersebut, diperlukan kemampuan literasi membaca yang baik. Dengan memiliki kemampuan literasi membaca yang baik, kita akan dapat memahami makna teks yang dihadirkan, secara literal, interpretatif, kritis, dan kreatif. Berdasarkan pemaparan tersebut, peneliti bermaksud untuk melakukan penelitian mengenai pengaruh kemampuan literasi membaca terhadap pemahaman moderasi bergama, khususnya pada mahasiswa tingkat I PGSD Kampus UPI di Purwakarta. Berdasarkan pemaparan tersebut, tujuan penelitian ini adalah untuk mengetahui kemampuan literasi membaca mahasiswa tingkat I Kampus UPI di Purwakarta, pemahaman moderasi beragama mahasiswa tingkat I Kampus UPI di Purwakarta, dan pengaruh kemampuan literasi membaca terhadap pemahaman moderasi beragama mahasiswa tingkat I Kampus UPI di Purwakarta.

Kemampuan literasi membaca yang telah dipaparkan sebelumnya, mengalami revisi pada tahun 2018. Kemampuan literasi saat ini bukan hanya berkiatan dengan kegiatan membaca saja, namun mengonstruksikan keterampilan tersebut, seperti interpretasi literal, integrasi kalimat, mengekstraksi tema dan inferensi, dan kemampuan berpikir kritis untuk memproses teks yang kompleks untuk tujuan tertentu. Penggunaan media digital dan teks digital juga dimanfaatkan dalam kegiatan membaca tersebut (Wulan, 2021).

Selama ini, penelitian yang berorientasi pada literasi membaca hanya menitik beratkan pada upaya untuk memahami cara penulis memaparkan gagasannya, memahami diksi yang digunakannya, dan memahami maksud yang disampaikannya pada ranah akademik kognitif. Sementara itu, literasi membaca juga sangat erat kaitannya dengan akademik afektif dan psikimotorik. Penelitian ini beorientasi pada ranah akademik kognitif dan afektif dengan menggunakan pemahaman moderasi beragama sebagai tolak ukur keberhasilan literasi membaca. Moderasi beragama yang erat dengan keberagaman di Indonesia menjadi salah satu materi yang hangat dibicarakan akhir-akhir ini. Bagi bangsa Indonesia, keragaman diyakini sebagai takdir. Ia tidak diminta, melainkan pemberian Tuhan Yang Mencipta, bukan untuk ditawar tapi untuk diterima (taken for granted). Indonesia adalah negara dengan keragaman etnis, suku, budaya, bahasa, dan agama yang nyaris tiada tandingannya di dunia. Keragaman dalam beragama itu niscaya, tidak mungkin dihilangkan. Ide dasar moderasi adalah untuk mencari persamaan dan bukan mempertajam perbedaan. 
Bila dianalogikan, moderasi adalah ibarat gerak dari pinggir yang selalu cenderung menuju pusat atau sumbu (centripetal), sedangkan ekstremisme adalah gerak sebaliknya menjauhi pusat atau sumbu, menuju sisi terluar dan ekstrem (centrifugal). Ibarat bandul jam, ada gerak yang dinamis, tidak berhenti di satu sisi luar secara ekstrem, melainkan bergerak menuju ke tengah-tengah (Tim Penyusun Kemenag Republik Indonesia, 2019).

Seorang yang moderat akan berusaha mengkompromikan kedua sisi tersebut. Ia bisa bergerak ke kiri memanfaatkan akalnya, tapi tidak diam ekstrem di tempatnya. Ia berayun ke kanan untuk berpedoman pada teks, dengan tetap memahami konteksnya. Indikator moderasi beragama yang akan digunakan adalah empat hal, yaitu: 1) komitmen kebangsaan; 2) toleransi; 3) anti-kekerasan; dan 4) akomodatif terhadap kebudayaan lokal (Tim Penyusun Kemenag Republik Indonesia, 2019). Keempat indikator ini dapat digunakan untuk mengenali seberapa kuat moderasi beragama yang dipraktikkan oleh seseorang di Indonesia, dan seberapa besar kerentanan yang dimiliki. Kerentanan tersebut perlu dikenali supaya kita bisa menemukenali dan mengambil langkah-langkah yang tepat untuk melakukan penguatan moderasi beragama.

Komitmen kebangsaan merupakan indikator yang sangat penting untuk melihat sejauh mana cara pandang, sikap, dan praktik beragama seseorang berdampak pada kesetiaan terhadap konsensus dasar kebangsaan, terutama terkait dengan penerimaan Pancasila sebagai ideologi negara, sikapnya terhadap tantangan ideologi yang berlawanan dengan Pancasila, serta nasionalisme. Sebagai bagian dari komitmen kebangsaan adalah penerimaan terhadap prinsip-prinsip berbangsa yang tertuang dalam Konstitusi UUD 1945 dan regulasi di bawahnya (Tim Penyusun Kemenag Republik Indonesia, 2019).

Toleransi merupakan sikap untuk memberi ruang dan tidak mengganggu hak orang lain untuk berkeyakinan, mengekspresikan keyakinannya, dan menyampaikan pendapat, meskipun hal tersebut berbeda dengan apa yang kita yakini. Dengan demikian, toleransi mengacu pada sikap terbuka, lapang dada, sukarela, dan lembut dalam menerima perbedaan. Toleransi selalu disertai dengan sikap hormat, menerima orang yang berbeda sebagai bagian dari diri kita, dan berpikir positif (Tim Penyusun Kemenag Republik Indonesia, 2019).

Sedangkan radikalisme, atau kekerasan, dalam konteks moderasi beragama ini dipahami sebagai suatu ideologi (ide atau gagasan) dan paham yang ingin melakukan perubahan pada sistem sosial dan politik dengan menggunakan cara-cara kekerasan/ekstrem atas nama agama, baik kekerasan verbal, fisik dan pikiran. Inti dari tindakan radikalisme adalah sikap dan tindakan seseorang atau kelompok tertentu yang menggunakan caracara kekerasan dalam mengusung perubahan yang diinginkan. Kelompok radikal umumnya menginginkan perubahan tersebut dalam tempo singkat dan secara drastis serta bertentangan dengan sistem sosial yang berlaku. Radikalisme sering dikaitkan dengan terorisme, karena kelompok radikal dapat melakukan cara apa pun agar keinginannya tercapai, termasuk meneror pihak yang tidak sepaham dengan mereka. Walaupun banyak yang mengaitkan radikalisme dengan agama tertentu, namun pada dasarnya radikalisme tidak hanya terkait dengan agama tertentu, tetapi bisa melekat pada semua agama (Tim Penyusun Kemenag Republik Indonesia, 2019).

Sedangkan praktik dan perilaku beragama yang akomodatif terhadap budaya lokal dapat digunakan untuk melihat sejauh mana kesediaan untuk menerima praktik amaliah keagamaan yang mengakomodasi kebudayaan lokal dan tradisi. Orang-orang yang moderat memiliki kecenderungan lebih ramah dalam penerimaan tradisi dan budaya lokal dalam perilaku keagamaannya, sejauh tidak bertentangan dengan pokok ajaran agama. Tradisi keberagamaan yang tidak kaku, antara lain, ditandai dengan kesediaan untuk menerima praktik dan perilaku beragama yang tidak semata-mata menekankan pada kebenaran normatif, melainkan juga menerima praktik beragama yang didasarkan pada keutamaan, tentu, sekali lagi, sejauh praktik itu tidak bertentangan dengan hal yang prinsipil dalam ajaran agama. Sebaliknya, ada juga kelompok yang cenderung tidak akomodatif terhadap tradisi dan kebudayaan, karena mempraktikkan tradisi dan budaya dalam beragama akan dianggap sebagai tindakan yang mengotori kemurnian agama (Tim Penyusun Kemenag Republik Indonesia, 2019). 
DOI: https://doi.org/10.31004/basicedu.v6i1.1927

\section{METODE PENELITIAN}

Penelitian ini menggunakan pendekatan kuantitatif. Metode penelitian yang digunakan adalah survey explanatory. Menurut Arikunto (2018) penelitian survei merupakan jenis penelitian yang ditujukan untuk menjelaskan fenomena yang terjadi dengan cara meneliti hubungan antar variabel yang diteliti dan pengujian kebenaran dilapangan. Pada umumnya, survei menggunakan kuesioner sebagai alat pengambil data. Survei menganut aturan pendekatan kuantitatif, yaitu semakin besar sampel, hasilnya semakin mencerminkan populasi.

Menurut Kerlinger (Sugiyono, 2012), metode survei yaitu penelitian yang dilakukan pada populasi besar maupun kecil, tetapi data yang dipelajari adalah data dari sampel yang diambil dari populasi tersebut, sehingga ditemukan kejadian-kejadian relatif, destribusi, dan hubungan-hubungan antar variabel sosiologis maupun psikologis. Berdasarkan pemaparan-pemeparan tersebut, peneliti menggunakan metode penelitian survey explanatory karena dipandang paling tepat untuk mengetahui pengaruh keterampilan literasi membaca terhadap pemahaman moderasi mahasiswa.

Populasi pada penelitian ini adalah seluruh mahasiswa tingkat I Kampus UPI di Purwakarta, yang diiambil dengan teknik random sampling, sehingga terkumpul 198 reponden yang berasal dari Kampus UPI di Purwakarta. Teknik pengumpulan data pada penelitian ini adalah tes dan kuesioner untuk mengumpulkan data primer. Tes dilakukan untuk mengetahui kemampuan literasi membaca pada mahasiswa tingkat I. Mahasiswa mengisi sejumlah soal yang dikembangkan berdasarkan teori literasi membaca. Pengisian kuesioner dilakukan untuk mengetahui pemahaman mahasiswa terhadap moderasi beragama. Kuesioner adalah daftar pertanyaan yang diberikan kepada orang lain yang bersedia memberikan respons (responden) sesuai dengan permintaan pengguna. Kuesioner yang disebarkan kepada responden berupa multiple choice questions yang sifatnya tertutup dengan berpedoman pada skala Likert. Responden dimintai tanggapannya atas pertanyaan-pertanyaan yang diberikan, apakah setuju atau tidak setuju, dan lain-lain. Teknik analisis data yang digunakan dalam penelitian ini adalah analisis data secara kualitatif dan kuantitatif.

Jenis data yang dipakai dalam penelitian ini adalah data primer. Data primer adalah pengambilan data yang dihimpun langsung oleh peneliti (Riduwan, 2006). Data primer diperoleh dengan melakukan tes kemampuan literasi membaca dan menyebarkan daftar pertanyaan yang tersruktur, dengan tujuan untuk mengumpulkan informasi dari mahasiswa tingkat I Kampus UPI di Purwakarta. Sumber data dalam penelitian ini adalah nilai dan skor masing-masing variabel, yang diperoleh dari tes kemampuan literasi membaca dan pengisian kuesioner yang telah dibagikan kepada mahasiswa tingkat I Kampus UPI di Purwakarta.

Kemampuan literasi membaca diukur berdasarkan indikator dari kemampuan membaca pemahaman yang dikembangkan Burns, Paul C.; Roe, Betty D.; Ross (2011) dan dipadukan dengan teori Abidin (2018), yaitu pemahaman literal, pemahaman interpretasi, pemahaman kritis, dan pemahaman kreatif. Sementara itu, pemahaman moderasi bergama diukur berdasarkan indikator moderasi beragama Tim Penyusun Kemenag Republik Indonesia (2019), yaitu komitmen kebangsaan, toleransi, anti-kekerasan, dan akomodatif terhadap kebudayaan lokal.

\section{HASIL DAN PEMBAHASAN}

Gambaran data hasil penelitian dapat digunakan untuk memperkaya pembahasan, melalui gambaran data tanggapan responden dapat diketahui bagaimana tanggapan responden terhadap setiap variabel yang sedang diteliti. Agar lebih mudah menginterpretasikan variabel yang sedang diteliti, dilakukan kategorisasi terhadap skor tanggapan responden. Prinsip kategorisasi jumlah skor tanggapan responden diadopsi dari bab sebelumnya. 
DOI: https://doi.org/10.31004/basicedu.v6i1.1927

\section{a. Variabel Kemampuan Literasi Membaca}

Pada variabel Literasi Membaca (X) dengan 198 responden. Berikut disajikan hasil secara keseluruhan mengenai variabel Literasi Membaca (X).

Tabel 1 Analisis Deskriptif Variabel Literasi Membaca (X)

\begin{tabular}{lccccc}
\hline & $\mathrm{N}$ & Minimum & Maximum & Mean & Std. Deviation \\
\hline $\begin{array}{l}\text { Kemampuan Literasi } \\
\text { Membaca }\end{array}$ & 198 & 15.00 & 100.00 & 66.2121 & 13.60410 \\
\hline Valid N (listwise) & 198 & & & & \\
\hline
\end{tabular}

Berdasarkan tabel 1 mengenai analisis deskriptif pada variabel Literasi Membaca (X). Dapat diketahui nilai maksimum yaitu sebesar 100 , kemudian nilai minimum yaitu sebesar 15 , nilai rata-rata yaitu sebesar 66,2121, dan nilai stnadar deviasi yaitu sebesar 13,60410.

\section{b. Variabel Moderasi Beragama (Y)}

Agar lebih mudah menginterpretasikan variabel yang sedang diteliti, dilakukan kategorisasi terhadap skor tanggapan responden. Prinsip kategorisasi jumlah skor tanggapan responden dalam penelitian ini menggunakan nilai rata-rata hitung sebagai acuan untuk menetapkan klasifiasi kategori penilaian. Perhitungan rata-rata digunakan untuk melihat kecenderungan jawaban dari item - item pernyataan dalam rangka menggambarkan kondisi dari masing-masing variabel yang diteliti. Klasifikasi kategori penilaian dalam penelitian ini ditetapkan berdasarkan jumlah skala pengukuran yang dipergunakan, yaitu sebanyak lima klasifikasi. Berikut ini disajikan persamaan untuk menghitung panjang kelas pada setiap interval.

Dalam penelitian ini nilai maksimum penilaian adalah lima dan nilai minimum penelitian adalah satu, sehingga apabila nilai disubsitusikan kedalam persamaan sebelumnya, diperoleh hasil 0,8. Berdasarkan hasil perhitungan panjang kelas setiap interval, pada gambar 4.1 disajikan klasifikasi kategori penilaian terhadap nilai rata-rata hitung, sebagai berikut.

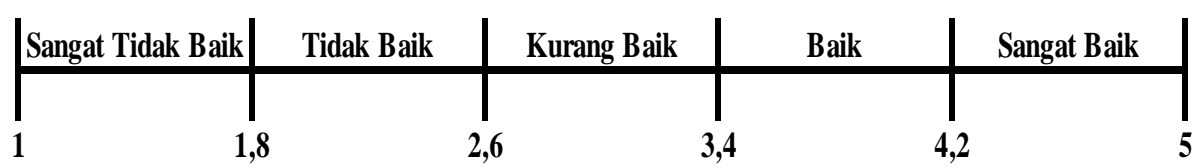

Gambar 1 Garis Kontinum

Pada variabel Moderasi Beragama (Y) memiliki 20 item pernyataan, dan 198 responden. Berikut disajikan hasil secara keseluruhan mengenai variabel Moderasi Beragama (Y).

Tabel 2 Rekapitulasi Analisis Deksriptif Variabel Moderasi Beragama (Y)

\begin{tabular}{|c|c|c|c|c|c|c|c|c|c|}
\hline \multirow{2}{*}{ No } & \multirow{2}{*}{ Butir Pernyataan } & & \multicolumn{5}{|c|}{ Skor Jawaban Responden } & \multirow{2}{*}{ Skor Total } & \multirow{2}{*}{ Mean } \\
\hline & & & 5 & 4 & 3 & 2 & 1 & & \\
\hline \multirow{2}{*}{1} & \multirow{2}{*}{ Pernyataan 1} & $\mathrm{~F}$ & 150 & 45 & 0 & 1 & 2 & \multirow{2}{*}{934} & \multirow{2}{*}{4,72} \\
\hline & & $\%$ & $75,76 \%$ & $22,73 \%$ & $0,00 \%$ & $0,51 \%$ & $1,01 \%$ & & \\
\hline \multirow{2}{*}{2} & \multirow{2}{*}{ Pernyataan 2} & $\mathrm{~F}$ & 110 & 81 & 5 & 2 & 0 & \multirow{2}{*}{893} & \multirow{2}{*}{4,51} \\
\hline & & $\%$ & $55,56 \%$ & $40,91 \%$ & $2,53 \%$ & $1,01 \%$ & $0,00 \%$ & & \\
\hline \multirow{2}{*}{3} & \multirow{2}{*}{ Pernyataan 3} & $\mathrm{~F}$ & 124 & 73 & 1 & 0 & 0 & \multirow{2}{*}{915} & \multirow{2}{*}{4,62} \\
\hline & & $\%$ & $62,63 \%$ & $36,87 \%$ & $0,51 \%$ & $0,00 \%$ & $0,00 \%$ & & \\
\hline 4 & Pernyataan 4 & $\mathrm{~F}$ & 20 & 92 & 34 & 43 & 9 & 665 & 3,36 \\
\hline
\end{tabular}


DOI: https://doi.org/10.31004/basicedu.v6i1.1927

\begin{tabular}{|c|c|c|c|c|c|c|c|c|c|}
\hline \multirow{3}{*}{ No } & \multirow{3}{*}{ Butir Pernyataan } & & \multicolumn{5}{|c|}{ Skor Jawaban Responden } & \multirow{3}{*}{ Skor Total } & \multirow{3}{*}{ Mean } \\
\hline & & & 5 & 4 & 3 & 2 & 1 & & \\
\hline & & $\%$ & $10,10 \%$ & $46,46 \%$ & $17,17 \%$ & $21,72 \%$ & $4,55 \%$ & & \\
\hline \multirow{2}{*}{5} & \multirow{2}{*}{ Pernyataan 5} & $\mathrm{~F}$ & 108 & 66 & 8 & 13 & 3 & \multirow{2}{*}{857} & \multirow{2}{*}{4,33} \\
\hline & & $\%$ & $54,55 \%$ & $33,33 \%$ & $4,04 \%$ & $6,57 \%$ & $1,52 \%$ & & \\
\hline \multirow{2}{*}{6} & \multirow{2}{*}{ Pernyataan 6} & $\mathrm{~F}$ & 100 & 70 & 17 & 7 & 4 & \multirow{2}{*}{849} & \multirow{2}{*}{4,29} \\
\hline & & $\%$ & $50,51 \%$ & $35,35 \%$ & $8,59 \%$ & $3,54 \%$ & $2,02 \%$ & & \\
\hline \multirow{2}{*}{7} & \multirow{2}{*}{ Pernyataan 7} & $\mathrm{~F}$ & 115 & 78 & 4 & 0 & 1 & \multirow{2}{*}{900} & \multirow{2}{*}{4,55} \\
\hline & & $\%$ & $58,08 \%$ & $39,39 \%$ & $2,02 \%$ & $0,00 \%$ & $0,51 \%$ & & \\
\hline \multirow{2}{*}{8} & \multirow{2}{*}{ Pernyataan 8} & $\mathrm{~F}$ & 125 & 67 & 4 & 2 & 0 & \multirow{2}{*}{909} & \multirow{2}{*}{4,59} \\
\hline & & $\%$ & $63,13 \%$ & $33,84 \%$ & $2,02 \%$ & $1,01 \%$ & $0,00 \%$ & & \\
\hline \multirow{2}{*}{9} & \multirow{2}{*}{ Pernyataan 9} & $\mathrm{~F}$ & 55 & 121 & 17 & 3 & 2 & \multirow{2}{*}{818} & \multirow{2}{*}{4,13} \\
\hline & & $\%$ & $27,78 \%$ & $61,11 \%$ & $8,59 \%$ & $1,52 \%$ & $1,01 \%$ & & \\
\hline \multirow{2}{*}{10} & Pernyataan 10 & $\mathrm{~F}$ & 1 & 51 & 37 & 65 & 44 & 494 & 240 \\
\hline & 1 thity aladil to & $\%$ & $0,51 \%$ & $25,76 \%$ & $18,69 \%$ & $32,83 \%$ & $22,22 \%$ & 474 & $2,+7$ \\
\hline 11 & Pernv & $\mathrm{F}$ & 119 & 61 & 5 & 13 & 0 & 880 & 4.44 \\
\hline 11 & Pernyataan 11 & $\%$ & $60,10 \%$ & $30,81 \%$ & $2,53 \%$ & $6,57 \%$ & $0,00 \%$ & 880 & 4,44 \\
\hline & & $\mathrm{F}$ & 74 & 77 & 29 & 16 & 2 & 700 & \\
\hline 12 & Pernyataan 12 & $\%$ & $37,37 \%$ & $38,89 \%$ & $14,65 \%$ & $8,08 \%$ & $1,01 \%$ & 799 & 4,04 \\
\hline 13 & Pernyataan 13 & $\mathrm{~F}$ & 24 & 56 & 57 & 45 & 16 & 621 & 314 \\
\hline $1 J$ & Teling aladal $1 \mathrm{~J}$ & $\%$ & $12,12 \%$ & $28,28 \%$ & $28,79 \%$ & $22,73 \%$ & $8,08 \%$ & 021 & 5,14 \\
\hline 14 & Pernyataan 14 & $\mathrm{~F}$ & 74 & 111 & 11 & 2 & 0 & 851 & 430 \\
\hline 14 & Teningatadil 14 & $\%$ & $37,37 \%$ & $56,06 \%$ & $5,56 \%$ & $1,01 \%$ & $0,00 \%$ & $0 J 1$ & 4,J0 \\
\hline & & $\mathrm{F}$ & 53 & 109 & 25 & 9 & 2 & & \\
\hline 15 & Pernyataan 15 & $\%$ & $26,77 \%$ & $55,05 \%$ & $12,63 \%$ & $4,55 \%$ & $1,01 \%$ & 796 & 4,02 \\
\hline 16 & Pernyataan 16 & $\mathrm{~F}$ & 96 & 97 & 2 & 3 & 0 & 880 & 444 \\
\hline 10 & I Cliny aladil io & $\%$ & $48,48 \%$ & $48,99 \%$ & $1,01 \%$ & $1,52 \%$ & $0,00 \%$ & 000 & $4,4+4$ \\
\hline 17 & Pernyataan 17 & $\mathrm{~F}$ & 110 & 86 & 2 & 0 & 0 & 900 & 455 \\
\hline 17 & Feningatadi it & $\%$ & $55,56 \%$ & $43,43 \%$ & $1,01 \%$ & $0,00 \%$ & $0,00 \%$ & 900 & $4, J 3$ \\
\hline 18 & Pernyataan 18 & $\mathrm{~F}$ & 109 & 82 & 6 & 0 & 1 & 802 & 451 \\
\hline 10 & Pernyatadin 10 & $\%$ & $55,05 \%$ & $41,41 \%$ & $3,03 \%$ & $0,00 \%$ & $0,51 \%$ & 092 & 4,J1 \\
\hline 10 & Pernuatagn 10 & $\mathrm{~F}$ & 58 & 82 & 22 & 27 & 9 & 747 & 377 \\
\hline 19 & Teliny aldant 19 & $\%$ & $29,29 \%$ & $41,41 \%$ & $11,11 \%$ & $13,64 \%$ & $4,55 \%$ & 141 & J, \\
\hline 20 & Pernyataan 20 & $\mathrm{~F}$ & 77 & 99 & 16 & 6 & 0 & 841 & 425 \\
\hline 20 & Pentinatadin 20 & $\%$ & $38,89 \%$ & $50,00 \%$ & $8,08 \%$ & $3,03 \%$ & $0,00 \%$ & 041 & $4,2 J$ \\
\hline & & To & al Skord & an Rata-r & & & & 16441 & 4,15 \\
\hline
\end{tabular}

Sumber: Pengolahan Data (2021)

Berdasarkan tabel tersebut dapat diketahui rata-rata tanggapan responden mengenai variabel Moderasi Beragama (Y). Dapat diketahui nilai skor total yaitu sebesar 16441, dan secara keseluruhan rata-rata tanggapan responden mengenai variabel Moderasi Beragama (Y) yaitu sebesar 4,15 termasuk dalam kategori baik. Adapun kriteria interpretasi skor pada variabel Moderasi Beragama (Y) dapat dilihat pada gambar 4.2 sebagai berikut. 


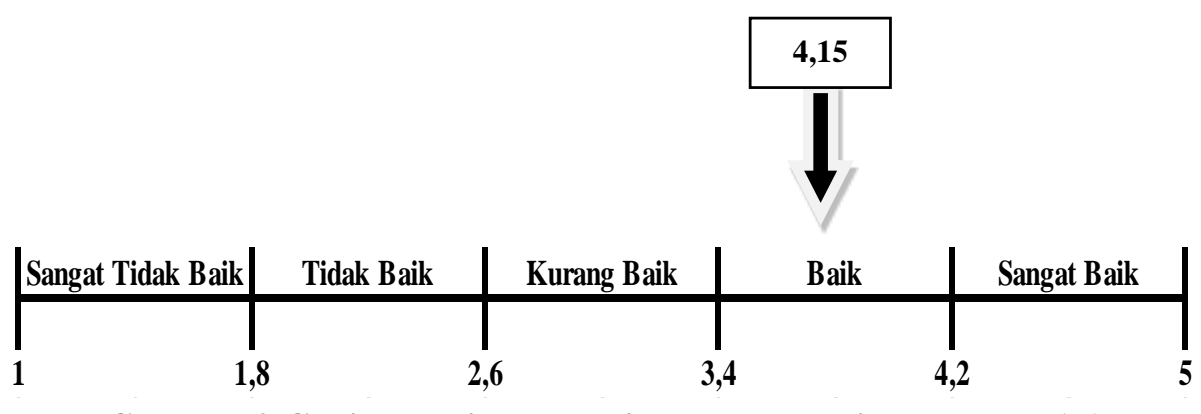

Gambar 2 Garis Kontinum Variabel Moderasi Beragama (Y)

Berdasarkan gambar tersebut mengenai garis kontinum pada variabel Moderasi Beragama (Y). Hasil tersebut menunjukkan bahwa tanggapan responden pada termasuk dalam kategori baik, yang ditunjukkan pada nilai rata-rata sebesar 4,15 berada pada rentang 3,4-4,2. Berdasarkan hasil tersebut dapat diambil kesimpulan bahwa tanggapan responden mengenai variabel Moderasi Beragama (Y) termasuk dalam kategori baik.

\section{1) Uji Asumsi Klasik}

Sebelum dilakukan pembentukan model regresi, terlebih dahulu dilakukan pengujian asumsi klasik agar model yang terbentuk memberikan estimasi yang BLUE (Best, Linear, Unbiased, Estimator). Pengujian asumsi ini terdiri atas dua pengujian, yakni uji Normalitas, dan uji Heteroskedastisitas.

\section{a. Uji Normalitas}

Dengan mengunakan bantuan aplikasi program SPSS versi 25.0 didapat output hasil perhitungan uji normalitas berikut:

Tabel 3 Uji Normalitas

\begin{tabular}{|c|c|c|}
\hline \multicolumn{3}{|c|}{ One-Sample Kolmogorov-Smirnov Test } \\
\hline \multicolumn{3}{|c|}{$\begin{array}{cc}\text { Unstandardized } \\
\text { Residual }\end{array}$} \\
\hline $\mathrm{N}$ & & 198 \\
\hline \multirow[t]{2}{*}{ Normal Parameters ${ }^{\mathrm{a}, \mathrm{b}}$} & Mean & .0000000 \\
\hline & Std. Deviation & .12224204 \\
\hline \multirow[t]{3}{*}{ Most Extreme Differences } & Absolute & .040 \\
\hline & Positive & .040 \\
\hline & Negative & -.037 \\
\hline Test Statistic & & .040 \\
\hline Asymp. Sig. (2-tailed) & & $200^{\mathrm{c}, \mathrm{c}}$ \\
\hline \multicolumn{3}{|l|}{ a. Test distribution is Normal. } \\
\hline \multicolumn{3}{|c|}{ b. Calculated from data. } \\
\hline \multicolumn{3}{|c|}{ c. Lilliefors Significance Correction. } \\
\hline d. This is a lower bound of & the true signifi & \\
\hline
\end{tabular}

Berdasarkan tabel tersebut, output SPSS diperoleh nilai Sig. uji normalitas dengan menggunakan metode Kolmogorov-Smirnovs sebesar 0,200. Dikarenakan nilai p-value tersebut lebih besar dari alpha $(0,200$ $>0,05)$, maka dapat disimpulkan bahwa residual data berdistribusi normal.

\section{b. Uji Heteroskedastisitas}

Uji Heterokedastisitas bertujuan menguji apakah dalam model regresi terjadi ketidaksamaan variansi dari residual satu pengamatan ke pengamatan yang lain. Model regresi yang baik adalah yang homokesdatisitas atau tidak terjadi heterokedastisitas. Salah satu cara yang digunakan untuk mendeteksi ada atau tidaknya heterokedastisitas adalah dengan menggunakan metode Glejser. Berikut merupakan hasil mengenai uji heteroskedastisitas yang mengunakan uji Glejser. 
DOI: https://doi.org/10.31004/basicedu.v6i1.1927

Tabel 4 Hasil Uji Heteroskedastisitas

\begin{tabular}{|c|c|c|c|c|c|c|}
\hline \multicolumn{7}{|c|}{ Coefficients $^{\mathbf{a}}$} \\
\hline & & \multicolumn{2}{|c|}{$\begin{array}{l}\text { Unstandardized } \\
\text { Coefficients }\end{array}$} & \multirow{2}{*}{$\begin{array}{r}\text { Standardized } \\
\text { Coefficients }\end{array}$} & \multirow[b]{2}{*}{$\mathrm{t}$} & \multirow[b]{2}{*}{ Sig. } \\
\hline \multicolumn{2}{|c|}{ Model } & $\mathrm{B}$ & Std. Error & & & \\
\hline 1 & (Constant) & 10.798 & 1.687 & & 6.400 & .000 \\
\hline & $\begin{array}{l}\text { Kemampuan Literasi } \\
\text { Membaca }\end{array}$ & -.061 & .025 & -.172 & -2.448 & .015 \\
\hline
\end{tabular}

Berdasarkan tabel mengenai uji heteroskedastisitas, dapat diketahui bahwa nilai signifikansi atau pvalue sebesar 0,015 lebih kecil dari alpha $(0,015<0,05)$, dengan demikian dapat disimpulkan bahwa terjadi gejala heteroskedastisitas. Untuk mengatasi hal tersebut salah satu caranya dengan menggunakan transformasi logaritma natural. Berikut merupakan hasil setelah dilakukan transformasi logaritma natural.

Tabel 5 Hasil Uji Heteroskedastisitas

\begin{tabular}{|c|c|c|c|c|c|c|}
\hline \multicolumn{7}{|c|}{ Coefficients $^{\mathbf{a}}$} \\
\hline \multirow{2}{*}{\multicolumn{2}{|c|}{ Model }} & \multicolumn{2}{|c|}{$\begin{array}{l}\text { Unstandardized } \\
\text { Coefficients }\end{array}$} & \multirow{2}{*}{$\begin{array}{l}\text { Standardized } \\
\text { Coefficients } \\
\text { Beta }\end{array}$} & \multirow[b]{2}{*}{$\mathrm{t}$} & \multirow[b]{2}{*}{ Sig. } \\
\hline & & $\mathrm{B}$ & Std. Error & & & \\
\hline 1 & (Constant) & .252 & .086 & & 2.938 & .004 \\
\hline & $\begin{array}{l}\text { Kemampuan Literasi } \\
\text { Membaca }\end{array}$ & -.037 & .021 & -.128 & -1.804 & .073 \\
\hline
\end{tabular}

Berdasarkan tabel tabel mengenai uji heteroskedastisitas, dapat diketahui bahwa nilai signifikansi atau p-value sebesar 0,073 lebih besar dari alpha $(0,073>0,05)$, dengan demikian dapat disimpulkan bahwa sudah tidak terjadi gejala heteroskedastisitas.

\section{2) Pengujian Hipotesis}

Hasil perhitungan pengujian parsial adalah sebagai berikut :

Tabel 6 Pengujian Hipotesis

\begin{tabular}{|c|c|c|c|c|c|c|}
\hline \multirow{2}{*}{\multicolumn{2}{|c|}{ Model }} & \multicolumn{2}{|c|}{$\begin{array}{l}\text { Unstandardized } \\
\text { Coefficients }\end{array}$} & \multirow{2}{*}{$\begin{array}{c}\begin{array}{c}\text { Standardized } \\
\text { Coefficients }\end{array} \\
\text { Beta }\end{array}$} & \multirow[b]{2}{*}{$\mathrm{t}$} & \multirow[b]{2}{*}{ Sig. } \\
\hline & & $\mathrm{B}$ & Std. Error & & & \\
\hline 1 & (Constant) & 3.300 & .144 & & 22.837 & .000 \\
\hline & $\begin{array}{l}\text { Kemampuan Literasi } \\
\text { Membaca }\end{array}$ & .222 & .035 & .417 & 6.421 & .000 \\
\hline
\end{tabular}

a. Dependent Variable: Moderasi Beragama

Hipotesis Penelitian:

$\mathrm{H}_{0} \quad$ : Kemampuan literasi membaca tidak berpengaruh signifkan terhadap moderasi beragama;

$\mathrm{H}_{1} \quad$ : Kemampuan literasi membaca berpengaruh signifkan terhadap moderasi beragama.

Kriteria pengujian:

Tolak $\mathrm{H}_{0}$ dan terima $\mathrm{H}_{1}$ jika $-\mathrm{t}_{\text {tabel }} \geq \mathrm{t}_{\text {hitung }} \geq \mathrm{t}_{\text {tabel }}$; atau

Terima $\mathrm{H}_{0}$ dan tolak $\mathrm{H}_{1}$ jika $-\mathrm{t}_{\text {tabel }}<\mathrm{t}_{\text {hitung }}<\mathrm{t}_{\text {tabel }}$. 
Tingkat signifikan $(\alpha)$ sebesar 5\%, dan derajat kebebasan $(v)=(n-(k+1))=198-(1+1)=196)$ didapat nilai $\mathrm{t}_{\text {tabel }} 1,972$.

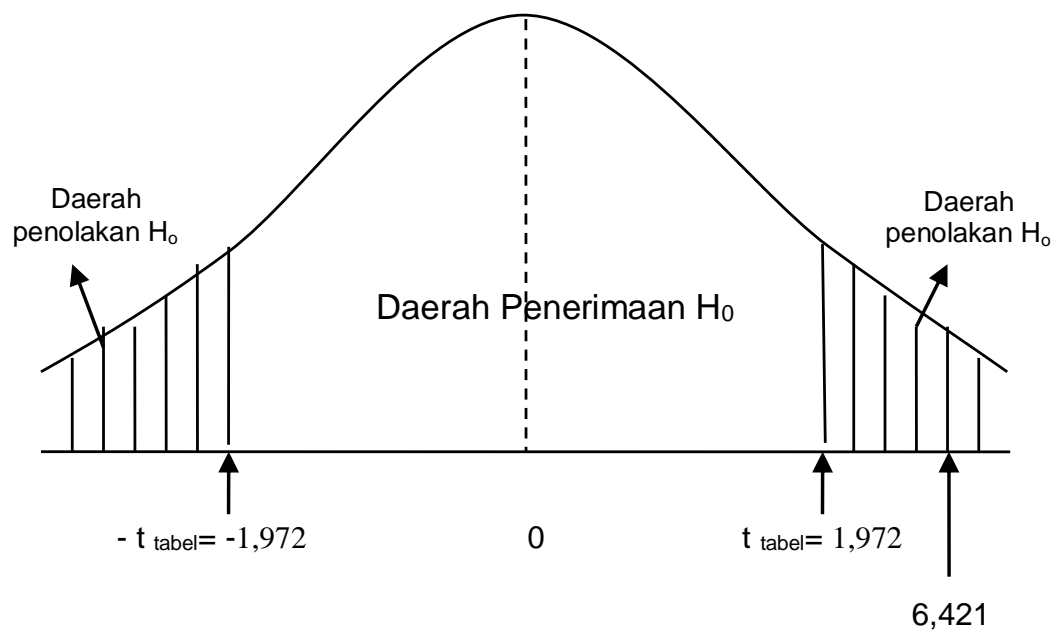

\section{Gambar 4. 1 Kurva Pengujian Hipotesis Kemampuan Literasi Membaca (X)}

Dari perhitungan tersebut, diperoleh nilai thitung untuk variabel Kemampuan Literasi Membaca (X) sebesar 6,421 dan $t_{\text {tabel }}$ 1,972. Dikarenakan nilai $t_{\text {hitung }}>t_{\text {tabel, }}$, maka $H_{0}$ ditolak dan $H_{1}$ diterima, artinya kemampuan literasi membaca berpengaruh signifikan terhadap moderasi beragama.

\section{PEMBAHASAN HASIL PENELITIAN}

Berikut ini adalah pembahasan hasil penelitian berdasarkan data yang telah dipaparkan sebelumnya.

\section{a. Kemampuan Literasi Mahasiswa}

Data isian angket dianalisis dengan cara menghitung persentase literasi membaca. Berdasarkan data penelitian, dapat diketahui bahwa nilai rata-rata mahasiswa pada variabel literasi membaca adalah 66,2. Berdasarkan kategori yang disampaikan oleh Arikunto (2010), maka literasi membaca mahasiswa tingkat I UPI Kampus Purwakarta dapat dikatakan cukup.

Literasi membaca mahasiswa Tingkat I UPI Kampus Purwakarta perlu ditingkatkan dengan berbagai cara untuk menunjang kebutuhan era globalisasi sebagai manusia yang literer. Literasi membaca mahasiswa pada rentang "cukup" belum menjadi sebuah kepuasan bagi peneliti. Faktor yang mempengaruhi hal tersebut diduga karena kurangnya minta membaca mahasiswa. Sejalan dengan pernyaataan Amalia \& Siregar (2018) bahwa kemampuan membaca dan memahami isi bacaan ini diduga disebabkan oleh kurangnya minat baca.

Siswati (2012) mengemukakan bahwa berdasarkan riset International Association for Evaluation of Educational Achievement (IAEEA) tentang minat baca dari 41 negara menginformasikan kemampuan membaca masyarakat Indonesia selevel dengan negara belahan bagian selatan Selandia Baru dan Afrika Selatan. Masih rendahnya kemauan masyarakat Indonesia dalam membaca dalam sistem pendidikan di Indonesia ini, membuat Indonesia masih tertinggal jauh dari negara Singapura maupun Malaysia dalam hal minat baca. Dalam riset bertajuk World's Most Literate Nations Ranked yang dilakukan oleh Central Connecticut State University di tahun 2016 lalu, Indonesia menduduki peringkat ke-60 dari 61 negara dengan tingkat literasi rendah. Sedangkan Finlandia menduduki peringkat pertama dengan tingkat literasi yang tinggi (hampir 100\%). Sedangkan data statistik dari UNESCO menunjukkan minat baca masyarakat Indonesia yang sangatlah memprihatinkan yaitu hanya $0,001 \%$ saja. Itu berarti, dari 1.000 orang Indonesia, hanya ada 1 orang 
yang rajin membaca. Selanjutnya, dari data penelitian yang dilakukan oleh United Nations Development Programme (UNDP), Indeks Pembangunan Manusia (IPM) di tingkat pendidikan yang ada di Indonesia juga masih tergolong rendah, yaitu $14,6 \%$. Jauh lebih rendah daripada Malaysia yang memiliki persentase hingga $28 \%$ (Anisa dkk., 2021).

Driana (2012) mengungkapkan bahwa permasalahan yang berkaitan dengan minat membaca merupakan penyakit yang dianggap darurat dalam penyelenggaraan pendidikan di Indonesia, sebab data-data tersebut menunjukkan salah satu kelemahan serius bangsa Indonesia setelah lebih dari 70 tahun merdeka (Tahmidaten \& Krismanto, 2020).

Ibrahim (2017) yang selaras dengan pendapat Tahmidaten \& Krismanto (2020) memaparkan bahwa setidaknya terdapat dua cara untuk meningkatkan budaya literasi membaca. Dua cara tersebut tidak sematamata untuk kepentingan evaluasi PISA sebagai alat ukur hasil belajar ataupun program- program asessmen keahlian membaca yang lainnya, namun yang paling utama adalah memperbaiki implementasi pelajaran membaca yang memang benar-benar dibangun untuk membentuk minat baca. Pertama, menemukenali sebabsebab terdalam kenapa seseorang kurang sabar dan teliti saat berhadapan dengan bacaan yang panjang. Kedua, merumuskan ulang paradigma pendidikan membaca, tidak hanya melalui mata pelajaran bahasa (Indonesia serta Inggris), tetapi menyusun model pendidikan membaca untuk semua mata pelajaran.

\section{b. Pemahaman Moderasi Beragama Mahasiswa}

Pemahaman moderasi beragama (variabel Y) dapat dilihat dari tanggapan responden terhadap variabel Y. Berdasarkan data penelitian, tampak bahwa indikator pemahaman moderasi beragama pada aspek toleransi memiliki persentase terendah sebesar 77, 3\% dengan kriteria baik, sedangkan persentase tertinggi terlihat pada akomodatif terhadap kebudayaan lokal sebesar $91 \%$ dengan kriteria sangat baik. Dari informasi yang diperoleh dapat disimpulkan bahwa pemahaman moderasi beragama mahasiswa UPI Kampus Purwakarta dapat dikatakan baik.

Persentase tertinggi pada aspek akomodatif terhadap kebudayaan lokal sekaligus menunjukkan bahwa mahasiswa UPI Kampus Purwakarta memiliki kecenderungan lebih ramah dalam penerimaan tradisi dan budaya lokal dalam perilaku keagamaannya yang tidak bertentangan dengan pokok ajaran agama. Akomodatif terhadap kebudayaan lokal dalam bahasa (Wahid, 2001) dikenal dengan pribumisasi Islam. Dalam gagasan pribumisasi Islam tergambar bagaimana Islam sebagai ajaran yang normatif berasal dari Tuhan diakomodasikan ke dalam kebudayaan yang berasal dari manusia tanpa kehilangan identitasnya masingmasing (Rahmat, 2003; Susanto \& Karimullah, 2017). Lebih lanjut, Maimun (2016) menjelaskan bahwa keputusan-keputusan dalam agama Islam harus senantiasa bersentuhan dengan budaya lokal yang berkembang di masyarakat. Perkembangan itu sebagai konsekuensi akomodasi dari dinamika pemikiran hukum Islam yang berhadapan dengan perubahan sosial, budaya, tradisi, ekonomi, hukum, politik, kemajuan ipteks informasi modern, dan tantangan perkembangan zaman yang senantiasa berubah sesuai dengan konteksnya.

Berbicara tentang pemahaman moderasi beragama di kalangan mahasiswa tentu sangat urgent. Pemahaman moderasi beragama yang baik, akan melahirkan sikap kebergamaan yang baik pula, yakni sikap beragama yang sedang atau di tengah-tengah dan tidak berlebihan. Tidak mengklaim diri atau kelompoknya yang paling benar, tidak menggunakan legitimasi teologis yang ekstrem, tidak menggunakan paksaan apalagi kekerasan, dan netral dan tidak berafiliasi dengan kepentingan politik atau kekuatan tertentu. Sikap moderasi tersebut perlu disosialisasikan, dididikkan, ditumbuh-kembangkan dengan suri teladan (Fahrudin, 2019).

Pemahaman moderasi beragama perlu diberikan kepada setiap orang yang beragama (Anwar, 2021), lebih lanjut pemahaman moderasi beragama juga perlu ditanamkan kepada mahasiswa, khususnya mahasiswa UPI Kampus Purwakarta sebagai generasi muda dan penerus (Christanti \& Anwar, 2019). Nilai moderat atau wasathiyah dalam moderasi beragama sangat penting untuk dipertahankan sebagai kesadaran kolektif umat Islam di Indonesia, khususnya mahasiswa muslim (Kudus, 2020). Kementerian agama mengusung model 
moderasi beragama hari ini untuk berfikir inklusif dan mengembalikan semangat kerjasama sebagai anggota masyarakat (Asrori, 2020).

Dengan mengadaptasi pendapat Anwar \& Muhayati (2021) yang menyatakan bahwa untuk membangun pemahaman moderasi beragama di kalangan mahasiswa, maka langkah yang dapat dilakukan oleh UPI Kampus Purwakarta adalah pertama, keberadaan mata kuliah PAI yang secara substansi diarahkan dalam pembentukan karakter Islam moderat bagi mahasiswa, hal ini dibuktikan dengan materi dan submateri pada mata kuliah PAI itu sendiri. Kedua, melalui keteladanan dosen PAI yang mengedepankan sikap moderat, hal ini penting dilakukan oleh dosen PAI yang merupakan role model bagi mahasiswa karena pembentukan karakter peserta didik diawali oleh pendidik itu sendiri, hal ini tercermin saat pembelajaran PAI di kelas ketika berhadapan langsung dengan mahasiswa serta berbagai aktivitas lainnya di kampus.

Ketiga, melalui diskusi dengan mahasiswa tentang pemahaman mereka tentang terjadi di masyarakat. Mahasiswa diminta untuk mengobservasi kasus yang berhubungan dengan moderasi beragama, sikap ekstremisme, dan radikalisme yang terjadi di lingkungan sekitar mereka. Melakukan riset lapangan dan melaporkannya untuk dipresentasikan dihadapan dosen dan mahasiswa lainnya, apabila terdapat hal-hal menyimpang, maka dosen memberikan pemahaman yang sebenarnya. Bila terdapat mahasiswa yang mempunyai pemahaman sedikit berlebihan dalam beragama, maka dosen memberikan penjelasan dan meluruskan kekeliruan pemahaman tersebut dengan tetap menjaga etika dalam menyeru kebaikan dalam Islam, tidak memaksa secara paksa dan memarahi mahasiswa tersebut.

Keempat, melalui penyesuaian kurikulum dalam mata kuliah PAI yang secara substansi mencakup metodologi memahami ajaran Islam, Al Quran, as sunnah dan Ijtihad, solusi Islam terhadap problematikan sosial budaya dan lingkungan, Ijtihad umat Islam tentang politik, moderasi Islam, wanita, dan budaya antikorupsi dan Islam sebagai rahmatan lil alamin. Kelima, program Tutorial PAI/SPAI. Mahasiswa yang sedang menempu PAI/SPAI diwajibkan mengikuti kegiatan tutorial sebagai syarat kelulusan PAI. Dosen PAI bekerjasama dengan mahasiswa yang tergabung dalam Tutorial PAI/SPAI.

Keenam, melalui pembinaan dan pendampingan Unit Kegiatan Mahasiswa (UKM). Adanya kegiatan kemahasiswaan yang diarahkan pada konsep toleransi, menghargai keberagaman, multikulural dan tidak mengandung unsur kekerasan, terkhusus kepada unit kegiatan mahasiswa berbasis keislaman di UPI Kampus Purwakarta untuk tetap mengedepankan sikap komitmen kebangsaan. Komitmen kebangsaan mahasiswa penting untuk dibangun sebagai upaya untuk melihat sejauh mana mahasiswa sebagai organisasi kelompok kemahasiswaan memndang dan berekspresi terhadap ideologi kebangsaan, terutama komitmen menerima Pancasila sebagai dasar negara.

Ketujuh, kegiatan lain yang menunjang dalam mewujudkan karakter mahasiswa yang moderat dan bermoral. Metode pembentukan moderasi beragama mahasiswa melalui kegiatan penunjang dilakukan melalui mengikuti seminar dengan tema kerukunan dan toleransi beragama, pemahaman agama Islam secara kaffah, dan pembentkan sikap moral agama.

\section{c. Pengaruh Literasi Membaca terhadap Pemahaman Moderasi Beragama Mahasiswa}

Terdapat pengaruh yang cukup signifikan antara literasi membaca dengan pemahaman moderasi beragama mahasiswa UPI Kampus Purwakarta melalui analisis regresi. Variabel literasi membaca berpengaruh sebesar 17,39\% terhadap pemahaman moderasi beragama mahasiswa UPI Kampus Purwakarta. Artinya $82,61 \%$ lagi dipengaruhi oleh variabel lain. Namun walaupun variabel literasi membaca hanya $21 \%$ tetapi antara variabel literasi membaca dengan pemahaman moderasi beragama mahasiswa UPI Kampus Purwakarta terdapat korelasi yang positif sebesar 0,417. Artinya semakin baik literasi membaca maka semakin sebaik pula pemahaman moderasi beragama mahasiswa/i UPI Kampus Purwakarta, sehingga literasi membaca terbukti dapat membentuk perilaku positif dan hal ini sejalan dengan penelitian Suarni dkk., (2019). Lebih lanjut Buwono \& Dewantara (2020) menyatakan bahwa literasi membaca mahasiswa dengan memanfaatkan 
media internet dapat memenuhi kebutuhan terhadap sikap positif mahasiswa dan tuntutan kecenderungan pembelajaran mandiri.

Pemahaman moderasi beragama mahasiswa juga dipengaruhi beberapa hal selain literasi membaca, yaitu, pertama, sosialisasi mengenai moderasi beragama. Kedua, koordinasi antara pemangku kepentingan dengan para tokoh agama, tokoh masyarakat dan dosen pendidikan agama Islam (Litiloly, 2020). Ketiga, Faktor lingkungan. Faktor lingkungan di luar perguruan tinggi sangat berpengaruh dalam menghambat terbentuknya pemahaman dan sikap moderasi beragama mahasiswa. Lingkungan tempat mahasiswa bergaul bisa membawa pengaruh bagi pengetahuan, sikap, dan kepribadian mahasiswa.

Dalam bukunya, Latief, Hilman; Irfan, Abubakar; Bamualim (2018) mengungkapkan bahwa pendidikan memberikan fondasi pada keberagamaan anak muda muslim. Sedangkan pertemanan, sangat berpengaruh pada corak keberagamaan anak muda apakah akan menuju moderat atau radikal. Hal tersebut menjadi bukti bahwa sekuat apapun fondasi moderasi beragama yang dibangun oleh dosen PAI di kampus, apabila lingkungan pergaulan di luar kampus adalah lingkungan radikal, maka sikap siswa akan menjadi radikal, begitu pula ketika lingkuan di luar kampus terlalu liberal, maka sikap mahasiswa akan menjadi liberal.

Keempat, faktor media sosial. Peran media sosial yang sulit dikontrol akan menghambat terbentuknya pemahaman moderasi beragama mahasiswa. Media sosial pada era sekarang ini memang menjadi sahabat dan tempat bertanya bagi anak muda muslim dalam belajar agama. Banyak anak muda yang mengikuti kajian atau konten-konten bernuansa Islam di media sosial karena dapat diakses dimanapun dan kapanpun dengan tema sesuai keinginan. Kajian-kajian yang ada di media sosial tidak semuanya moderat, ada yang cenderung ke arah radikal bahkan ada juga konten yang arahnya kepada liberalisme. Oleh karenanya, wajar jika kemudian media sosial meredukasi peran sekolah maupun keluarga dalam aktivitas mempelajari agama. Amalee (2017) dalam bukunya mengungkapkan banyak sekali berita online, broadcase BBM, dan Whatsaap yang mulai berseliweran menyebarkan kajian Islami dengan dalil ini itu, dan tanpa pikir panjang, tanpa cross-check langsung dishare. Hal inilah yang dapat menghambat pemahaman moderasi beragama mahasiswa.

Selanjutnya, dalam melaksanakan penelitian, peneliti mengalami beberapa keterbatasan dan diharapkan dapat menjadi stimulus untuk dapat diperhatikan bagi peneliti-peneliti yang akan datang dalam menyempurnakan penelitiannya. Keterbatasn yang dimaksud adalah 1) subjek penelitian yang hanya difokuskan pada mahasiswa PGSD; 2) jumlah responden yang hanya 198 dan masih kurang dalam menggambarkan keadaan yang sesungguhnya; 3) dalam proses pengambian data, informasi yang diberikan responden melalui kuesioner terkadang tidak menunjukkan pendapat responden yang sebenarnya, hal ini terjadi karena kadang perbedaan pemikiran, anggapan dan pemahaman yang berbeda tiap responden, juga faktor lain seperti faktor kejujuran dalam pengisian pendapat responden dalam kuesionernya.

\section{KESIMPULAN}

Berdasarkan hasil analisis penelitian, maka dapat dapat diambil kesimpulan bahwa kemampuan literasi membaca mahasiswa masih tergolong cukup baik dengan rata-rata nilai tes 66,2. Nilai tertinggi adalah 100 dan nilai terendah adalah 15. Pemahaman moderasi bergama secara keseluruhan memiliki nilai persentase kumulatif sebesar $85,28 \%$ dengan kategori baik. Kemampuan literasi membaca berpengaruh signifikan terhadap pemahaman moderasi beragama, dengan total persentase pengaruh sebesar $17,39 \%$, sedangkan sisanya yaitu $82,61 \%$ dipengaruhi oleh faktor lain yang tidak diteliti. Pemahaman moderasi beragama mahasiswa PGSD yang baik terbukti berimplikasi terhadap sikap positif mahasiswa, sehingga diharapkan perguruan tinggi dapat menyediakan fasilitas yang mendukung peningkatan literasi membaca mahasiswa demi mendukung terwujudnya sumber daya manusia yang dapat menginisiasi semangat moderasi beragama di perguruan tinggi. 


\section{DAFTAR PUSTAKA}

Abidin, Y. (2018). Pembelajaran Multiliterasi Sebuah Jawaban Atas Tantangan Pendidikan Abad Ke-21 Dalam Konteks Keindonesiaan. Bandung: Pt Refika Aditama.

Amalee, I. (2017). Islam Itu Ramah, Bukan Marah. Jakarta: Noura Book.

Amalia, N., \& Siregar, A. (2018). Faktor-Faktor Yang Mempengaruhi Literasi Membaca Bahasa Indonesia Yang Berkemajuan. Prosiding Pekan Seminar Nasional, 01(01), 255-274. Https://Journal.Uhamka.Ac.Id/Index.Php/Pesona/Article/View/2361

Anisa, A. R., Ipungkarti, A. A., \& Saffanah, K. N. (2021). Pengaruh Kurangnya Literasi Serta Kemampuan Dalam Berpikir Kritis Yang Masih Rendah Dalam Pendidikan Di Indonesia. Current Research In Education: Conference Series Journal, 1(1), 1-12.

Anwar, R. N. (2021). Penanaman Nilai-Nilai Islam Moderat Pada Anak Usia Dini Dalam Keluarga Sebagai Upaya Menangkal Radikalisme. Al Fitrah: Journal Of Early Childhood Islamic Education, 4(2), 155163. Https://Doi.Org/Http://Dx.Doi.Org/10.29300/Alfitrah.V4i2.3883

Anwar, R. N., \& Muhayati, S. (2021). Upaya Membangun Sikap Moderasi Beragama Melalui Pendidikan Agama Islam Pada Mahasiswa Perguruan Tinggi Umum. Al-Tadzkiyyah: Jurnal Pendidikan Islam, 12(1), 1-15. Https://Doi.Org/Https://Doi.Org/10.24042/Atjpi.V12i1.7717

Arikunto, S. (2010). Prosedur Penelitian Suatu Pendekatan Praktik. Jakarta: Pt Rineka Cipta.

Arikunto, S. (2018). Prosedur Penelitian Suatu Pendekatan Praktik. Jakarta: Pt Rineka Cipta.

Asrori, S. (2020). Lanskap Moderasi Keagamaan Santri, Refleksi Pola Pendidikan Pesantren. Jurnal Ilmu Sosial Indonesia, 1(1), 16-26. Https://Journal.Uhamka.Ac.Id/Index.Php/Pesona/Article/View/2361

Burns, Paul C.; Roe, Betty D.; Ross, E. P. (2011). Teadhing Reading In Today's Elementary School. Boston: Houghton Mifflin.

Buwono, S., \& Dewantara, J. A. (2020). Hubungan Media Internet, Membaca, Dan Menulis Dalam Literasi Digital Mahasiswa. Jurnal Basicedu, 4(4), 1186-1193. Https://Doi.Org/10.31004/Basicedu.V4i4.526

Christanti, Y. D., \& Anwar, R. N. (2019). Hubungan Prokrastinasi Akademik Dengan Kecerdasan Spiritual Generasi Milenial. Pedagogik: Jurnal Pendidikan, 6(1), 31-65. Https://Doi.Org/Https://Doi.Org/10.33650/Pjp.V6i1.486

Driana, E. (2012, Desember 14). Gawat Darurat Pendidikan. Kompas.Com. Https://Nasional.Kompas.Com/Read/2012/12/14/02344589/Gawat.Darurat.Pendidikan

Fahrudin, F. (2019, Januari 21). Pentingnya Moderasi Beragama Bagi Kaum Milenial. Republika. Https://Www.Republika.Co.Id/Berita/Plntgz384/Pentingnya-Sikap-Moderasi-Beragama-Bagi-KaumMilenial

Ibrahim, G. (2017, April 30). Pisa Dan Daya Baca Bangsa. Https://Nasional.Kompas.Com/Read/2017/04/30/11135891/Pisa.Dan.Daya.Baca.Bangsa

Tim Penyusun Kementerian Agama Indonesia. (2019). Moderasi Beragama. Jakarta: Badan Litbang Dan Diklat Kementerian Agama Ri.

Kudus, H. H. I. (2020). Penerapan Nilai-Nilai Moderasi Islam Dalam Pembelajaran Fiqih Di Ptkin Menggunakan Konsep Problem Basic Learning. Jipis, 29(1), 27-35. Https://Doi.Org/Https://Doi.Org/10.33592/Jipis.V29i1.546

Latief, Hilman; Irfan, Abubakar; Bamualim, C. S. (2018). Kaum Muda Muslim Milenial: Konservatisme, Hibridasi Identitas, Dan Tantangan Radikalisme. Center For The Sudy Of Religion And Culture (Csrc).

Litiloly, A. (2020). Implementasi Kebijakan Penguatan Moderasi Beragama Di Lingkungan Kementerian Agama Kota Ambon. 12 Waiheru: Jurnal Diklat Keagamaan Ambon, 6(1), 102-118.

Maimun, M. (2016). Akomodasi Budaya Lokal Dalam Fatwa-Fatwa Nahdlatul Ulama. Asas: Jurnal Hukum 
385 Pengaruh Literasi Membaca terhadap Pemahaman Moderasi Beragama Mahasiswa PGSD - Neneng Sri Wulan, Hisny Fajrussalam

DOI: https://doi.org/10.31004/basicedu.v6i1.1927

Ekonomi Syariah, 8(1), 102-120. Https://Doi.Org/Https://Doi.Org/10.24042/Asas.V8i1.1228

Rahmat, M. I. (2003). Islam Pribumi: Mencari Wajah Islam Indonesia. Tashwirul Afkar: Jurnal Refleksi Pemikiran Keagamaan Dan Kebudayaan, 4, 9-32. Http://Psqdigitallibrary.Com/Pustaka/Index.Php?P=Fstream\&Fid=1088\&Bid=3358

Riduwan, R. (2006). Skala Pengukuran Variabel-Variabel Penelitian. Bandung: Alfabeta.

Siswati, S. (2012). Minat Membaca Pada Mahasiswa (Studi Deskriptif Pada Mahasiswa Fakultas Psikologi $\begin{array}{lllll}\text { Undip } & \text { Semester } & \text { I). } & \text { Jurnal } & \text { Psikologi, }\end{array}$ Https://Doi.Org/Https://Doi.Org/10.14710/Jpu.8.2.124-134

Suarni, N., Taufina, T., \& Zikri, A. (2019). Literasi Membaca Meningkatkan Karakter Positif Siswa Sekolah Dasar. Jurnal Basicedu, 3(4), 1014-1021. Https://Doi.Org/10.31004/Basicedu.V3i4.215

Sugiyono, S. (2012). Metode Penelitian. Alfabeta.

Susanto, E., \& Karimullah, K. (2017). Islam Nusantara: Islam Khas Dan Akomodatif Terhadap Budaya Lokal. Al-Ulum, 16(1), 56-80. Https://Doi.Org/10.30603/Au.V16i1.27

Tahmidaten, L., \& Krismanto, W. (2020). Permasalahan Budaya Membaca Di Indonesia (Studi Pustaka Tentang Problematika \& Solusinya). Scholaria: Jurnal Pendidikan Dan Kebudayaan, 10(1), 22-33. Https://Doi.Org/Https://Doi.Org/10.24246/J.Js.2020.V10.I1.P22-33

Wahid, A. (2001). Pergulatan Negara, Agama Dan Kebudayaan. Jakarta: Dedsantara.

Wulan, N. S. (2021). Pengembangan Model Literasi Keluarga Berbasis Simplifikasi Cerita Rakyat. Sleman: $\mathrm{Cv}$ Pena Persada. 